\title{
Prediction of the Impact of Air Pollution on Rates of Hospitalization for Asthma in Shiraz Based on Air Pollution Indices in 2007-2012
}

\author{
Mozhgan Moghtaderi', Marjan Zarei ${ }^{2}$, Shirin Farjadian ${ }^{1,3}{ }^{*}$, Shahrooz Shamsizadeh ${ }^{4}$ \\ ${ }^{1}$ Allergy Research Center, Shiraz University of Medical Sciences, Shiraz, Iran \\ ${ }^{2}$ Department of Epidemiology, Shiraz University of Medical Sciences, Shiraz, Iran \\ ${ }^{3}$ Department of Immunology, Shiraz University of Medical Sciences, Shiraz, Iran \\ ${ }^{4}$ Specific Center of Occupational Medicine, Shiraz University of Medical Sciences, Shiraz, Iran \\ Email: ${ }^{*}$ farjadsh@sums.ac.ir
}

Received 1 March 2016; accepted 4 June 2016; published 7 June 2016

Copyright (C) 2016 by authors and Scientific Research Publishing Inc.

This work is licensed under the Creative Commons Attribution-NonCommercia International License (CC

BY-NC).

http://creativecommons.org/licenses/by-nc/4.0/

(c) (i) (9) Open Access

\begin{abstract}
Objectives: This study was designed to determine the effects of air pollutants on emergency admissions for asthma, and to forecast the disease burden in Shiraz, Iran. Methods: The average daily concentrations of fine particles $\left(\mathrm{PM}_{10}\right)$, nitrogen dioxide $\left(\mathrm{NO}_{2}\right)$, sulfur dioxide $\left(\mathrm{SO}_{2}\right)$, carbon monoxide ( $\mathrm{CO}$ ) and ozone $\left(\mathrm{O}_{3}\right)$ were calculated from data reported by two air quality monitoring stations in Shiraz from the beginning of 2007 to mid-2012. Results: The numbers of patients admitted with asthma attack during this period were collected from four main university-affiliated hospitals. Admissions were correlated strongly with the levels of $\mathrm{PM}_{10}, \mathrm{SO}_{2}, \mathrm{CO}$ and $\mathrm{O}_{3}$ during warm seasons $(\mathrm{P}<0.001)$, and with $\mathrm{NO}_{2}$ level during cold seasons $(\mathrm{P}<0.001)$. We forecast increasing trends in air pollutants and patient admissions in the year 2015. Conclusion: Our findings are further evidence of the effects of air pollutants on asthma exacerbations.
\end{abstract}

\section{Keywords}

Air Pollution, Asthma Attack, Iran, Carbon Monoxide, Nitrogen Dioxide, Sulfur Dioxide, Ozone, Particulate Matter

\section{Introduction}

Asthma is a chronic respiratory disease that worsens with exposure to allergens, viral respiratory infections and "Corresponding author.

How to cite this paper: Moghtaderi, M., Zarei, M., Farjadian, S. and Shamsizadeh, S. (2016) Prediction of the Impact of Air Pollution on Rates of Hospitalization for Asthma in Shiraz Based on Air Pollution Indices in 2007-2012. Open Journal of Air Pollution, 5, 37-43. http://dx.doi.org/10.4236/ojap.2016.52004 
air pollutants [1]-[3]. Numerous epidemiologic studies emphasis that air pollutants are important factors in exacerbations and hospital admissions for asthma [4]-[6]. Outdoor air contaminants consist of primary pollutants emitted directly into the atmosphere, such as sulfur dioxide $\left(\mathrm{SO}_{2}\right)$, nitrogen dioxide $\left(\mathrm{NO}_{2}\right)$, carbon monoxide (CO) and particulate matter (PM), along with secondary pollutants that form in the air as a result of chemical reactions with other pollutants and gases such as ozone $\left(\mathrm{O}_{3}\right)$, nitrogen oxide species and some particles [7]. Air pollutants can be produced from point or mobile sources. Point sources emit pollutants into the air from a fixed location such as power plants, chemical plants and other industrial facilities. Mobile sources include cars, trucks and vehicles [8].

Shiraz, the capital of Fars province, has a total area $240 \mathrm{~km}^{2}$ and a population of around 1.5 million (in 2012), making it the fifth largest city in Iran. It is located in the Zagros Mountain range in southwestern Iran at an elevation of 1486 meters above sea level. The city has a temperate climate with four distinct seasons and an average annual rainfall of about $300 \mathrm{~mm}$. Industrial activities in the city include an oil refinery, a thermal power plant and a cement factory. In addition to air pollution, this city is influenced by meteorological phenomena characteristic of the Middle East, such as dust storms originating from Iraq in warm seasons.

Although air pollution is an important public health problem in large cities in Iran, few studies have centered on the effects of air pollutants on asthma admission rates. The purposes of this study were to investigate the association between air pollution and admission rates of patients with asthma attacks from 2007 to 2012, and to predictthe future asthma disease burden in Shiraz.

\section{Methods}

\subsection{Data Collection}

To retrieve the medical records of patients admitted with asthma attack, we reviewed the admissions lists of four main university-affiliated hospitals (Namazee, Faghihi, Dastghaib and Aliasghar Hospital) in Shiraz from the beginning of 2007 to mid-2012. In addition to demographic information, the date of admission and duration of the hospital stay were extracted from their files.

Data on the daily levels of $\mathrm{PM}_{10}, \mathrm{SO}_{2}, \mathrm{NO}_{2}$, $\mathrm{CO}$ and $\mathrm{O}_{3}$ were obtained from two Environmental Protection Department automatic air quality monitoring stations located near the city center and in the northern part of Shiraz. The period from April to September was considered to comprise the warm seasons, and the period October to March was considered the cold seasons.

\subsection{Statistical Analysis}

The average daily concentration of each pollutant was calculated from data reported by the two monitoring stations. The associations between daily, monthly, seasonal and annual mean levels of $\mathrm{PM}_{10}, \mathrm{SO}_{2}, \mathrm{NO}_{2}, \mathrm{CO}$ and $\mathrm{O}_{3}$ and the number of patients admitted due to asthma attack were determined by calculating Pearson correlation coefficients for each interval during the 5.5-year study period. All statistical analyses were done with SPSS version 19.0 (SPSS Inc., Chicago, IL, USA), and two-tailed P values less than 0.05 were considered statistically significant. An autoregressive integrated moving average (ARIMA) model was used to forecast monthly admission rates to 2015 of patients with asthma in relation to each of the five air pollutants studied here.

\section{Results and Discussion}

During the 5.5-year study period, 1939 patients (931 males and 1008 females, age range 2 to 106 years, mean age $44.22 \pm 26.16$ years) were admitted for asthma exacerbation to one of the four participating hospitals. About one fifth of the patients (416, 21.5\%) were younger than 18 years, and 457 (23.5\%) were older than 65 years. The number of daily admissions varied from zero to 13 . The patients were hospitalized for periods ranging from 1 day to 1 month (average 4.7 days). Table 1 shows the annual mean concentrations of five major air pollutants and the number of patients admitted for asthma attack. Monthly variations in air pollutant levels and the numbers of patients admitted are shown in Figure 1. The monthly mean concentrations of $\mathrm{SO}_{2}, \mathrm{NO}_{2}$ and $\mathrm{O}_{3}$ correlated with admission rates during the study period $(\mathrm{P}<0.001)$. The levels of $\mathrm{PM}_{10}, \mathrm{SO}_{2}, \mathrm{CO}$ and $\mathrm{O}_{3}$ correlated strongly with admissions during the warm seasons $(\mathrm{P}<0.001)$, whereas $\mathrm{NO}_{2}$ levels correlated with patient admissions during the cold seasons $(\mathrm{P}<0.001)$.

There is growing epidemiological evidence of associations between air pollution and respiratory disorders in 
Table 1. Annual concentrations of five major air pollutants and their correlations with daily admissions of patients for asthma attack.

\begin{tabular}{|c|c|c|c|c|c|}
\hline $\mathrm{O}_{3}(\mathrm{ppm})$ & CO (ppm) & $\mathrm{NO}_{2}(\mathrm{ppm})$ & $\mathrm{SO}_{2}(\mathrm{ppm})$ & $\mathrm{PM}_{10}\left(\mu \mathrm{g} / \mathrm{m}^{3}\right)$ & Year \\
\hline & & & & & 2007 \\
\hline $0.010 \pm 0.006$ & $5.343 \pm 1.482$ & $0.026 \pm 0.005$ & $0.183 \pm 0.031$ & $89.218 \pm 47.48$ & Mean \pm SD \\
\hline 0.001 & 1.617 & 0.013 & 0.129 & 13.1 & Min \\
\hline 0.033 & 9.063 & 0.043 & 0.254 & 331.3 & Max \\
\hline 0.085 & 2.01 & 0.006 & 0.051 & 50.36 & Interquartile range \\
\hline 218 & 218 & 218 & 218 & 218 & Annual admissions \\
\hline \multirow[t]{2}{*}{0.06} & 0.32 & 0.06 & 0.13 & 0.01 & P-value \\
\hline & & & & & 2008 \\
\hline $0.010 \pm 0.006$ & $4.338 \pm 1.087$ & $0.022 \pm 0.004$ & $0.232 \pm 0.057$ & $102.66 \pm 97.50$ & Mean \pm SD \\
\hline 0.001 & 1.482 & 0.002 & 0.148 & 21.29 & Min \\
\hline 0.07 & 8.134 & 0.034 & 0.393 & 966.5 & Max \\
\hline 0.008 & 1.477 & 0.007 & 0.108 & 55.17 & Interquartile range \\
\hline 417 & 417 & 417 & 417 & 417 & Annual admissions \\
\hline \multirow[t]{2}{*}{0.00} & 0.20 & 0.01 & 0.001 & 0.06 & P-value \\
\hline & & & & & 2009 \\
\hline $0.013 \pm 0.007$ & $1.189 \pm 0.862$ & $0.026 \pm 0.007$ & $0.057 \pm 0.092$ & $115.68 \pm 86.00$ & Mean \pm SD \\
\hline 0.003 & 1.189 & 0.005 & 0.005 & 23.97 & Min \\
\hline 0.099 & 5.731 & 0.074 & 0.36 & 980 & Max \\
\hline 0.01 & 0.726 & 0.008 & 0.01 & 96.49 & Interquartile range \\
\hline 360 & 366 & 360 & 366 & 366 & Annual admissions \\
\hline \multirow[t]{2}{*}{0.005} & 0.03 & 0.35 & 0.07 & 0.4 & P-value \\
\hline & & & & & 2010 \\
\hline $0.015 \pm 0.007$ & $2.689 \pm 1.007$ & $0.046 \pm 0.014$ & $0.011 \pm 0.003$ & $96.70 \pm 61.22$ & Mean \pm SD \\
\hline 0.005 & 0.94 & 0.013 & 0.003 & 34 & Min \\
\hline 0.061 & 6.60 & 0.082 & 0.022 & 698.6 & Max \\
\hline 0.011 & 1.16 & 0.018 & 0.004 & 96.49 & Interquartile range \\
\hline 338 & 338 & 338 & 338 & 338 & Annual admissions \\
\hline \multirow[t]{2}{*}{0.00} & 0.00 & 0.003 & 0.12 & 0.28 & P-value \\
\hline & & & & & 2011 \\
\hline $0.026 \pm 0.012$ & $1.747 \pm 0.681$ & $0.018 \pm 0.009$ & $0.005 \pm 0.003$ & $109.812 \pm 52.747$ & Mean \pm SD \\
\hline 0.006 & 0.403 & 0.004 & 0.001 & 18 & Min \\
\hline 0.077 & 5.12 & 0.073 & 0.016 & 425.5 & Max \\
\hline 0.014 & 0.073 & 0.005 & 0.004 & 50.11 & Interquartile range \\
\hline 454 & 454 & 454 & 454 & 454 & Annual admissions \\
\hline \multirow[t]{2}{*}{0.01} & 0.12 & 0.21 & 0.38 & 0.33 & P-value \\
\hline & & & & & first 6 months of 2012 \\
\hline $0.031 \pm 0.010$ & $1.447 \pm 0.455$ & $0.014 \pm 0.002$ & $0.003 \pm 0.002$ & $148.329 \pm 180.02$ & Mean \pm SD \\
\hline 0.015 & 0.371 & 0.008 & 0.001 & 24.74 & Min \\
\hline 0.061 & 2.674 & 0.018 & 0.009 & 1901 & Max \\
\hline 0.014 & 0.69 & 0.003 & 0.002 & 81.90 & Interquartile range \\
\hline 163 & 163 & 163 & 163 & 163 & Annual admissions \\
\hline \multirow[t]{2}{*}{0.09} & 0.23 & 0.36 & 0.21 & 0.11 & P-value \\
\hline & & & & & 2007 till mid-2012 \\
\hline $0.01 \pm 0.01$ & $3.25 \pm 1.67$ & $0.026 \pm 0.01$ & $0.092 \pm 0.1$ & $106.86 \pm 88.62$ & Mean \pm SD \\
\hline 0.001 & 0.37 & .002 & 0.001 & 13.10 & Min \\
\hline 0.099 & 9.06 & 0.082 & 0.393 & 1901 & Max \\
\hline 0.013 & 2.48 & 0.004 & 0.17 & 60.59 & Interquartile range \\
\hline 1939 & 1939 & 1939 & 1939 & 1939 & Total admissions \\
\hline 0.03 & 0.06 & 0.00 & 0.005 & 0.06 & P-value \\
\hline
\end{tabular}

$\mathrm{PM}_{10}$, particulate matter $\leq 10 \mu \mathrm{m}$ in diameter; $\mathrm{SO}_{2}$, sulfur dioxide; $\mathrm{NO}_{2}$, nitrogen dioxide; $\mathrm{CO}$, carbon monoxide; $\mathrm{O}_{3}$, ozone. * , significant correlation (2-tailed P-value $<0.05)$.

developing countries [9]. We found positive associations between outdoor levels of $\mathrm{NO}_{2}, \mathrm{SO}_{2}$ and $\mathrm{O}_{3}$ and monthly admission rates of patients with asthma attacks in Shiraz.

The possible effects of $\mathrm{NO}_{2}$ in the air include increased sensitivity to respiratory viral infections and enhanced reactions to allergens (e.g., house dust mites), which exacerbates asthma and reduces lung function in children [10]-[12]. The results of our findings on the adverse effects of $\mathrm{NO}_{2}$ for patients in Shiraz are consistent with 


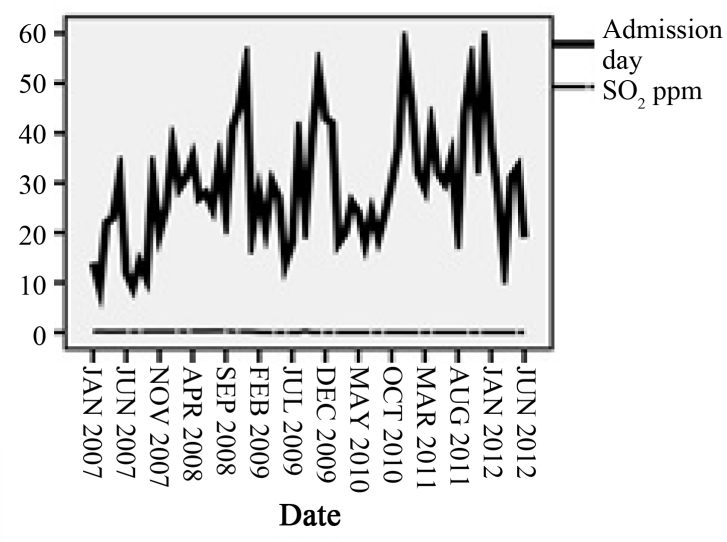

(a)

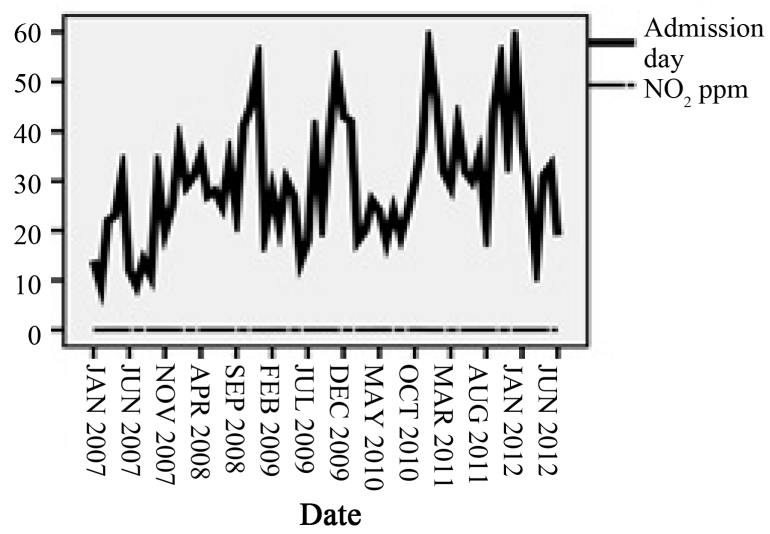

(c)

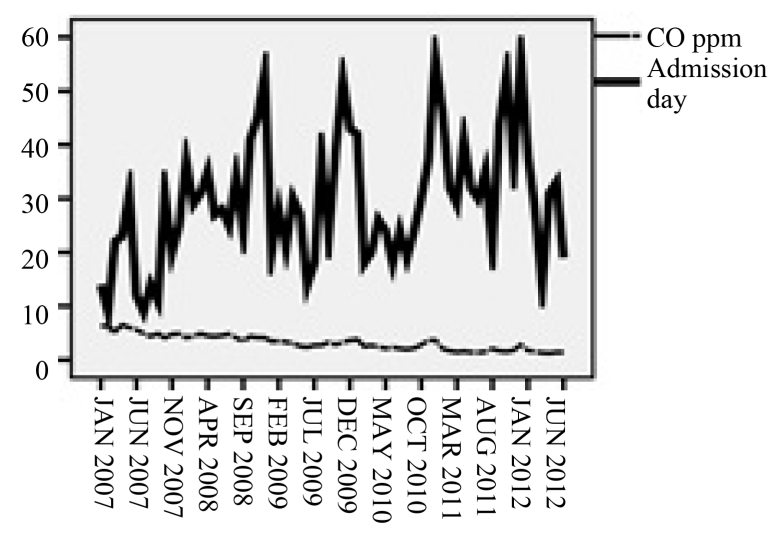

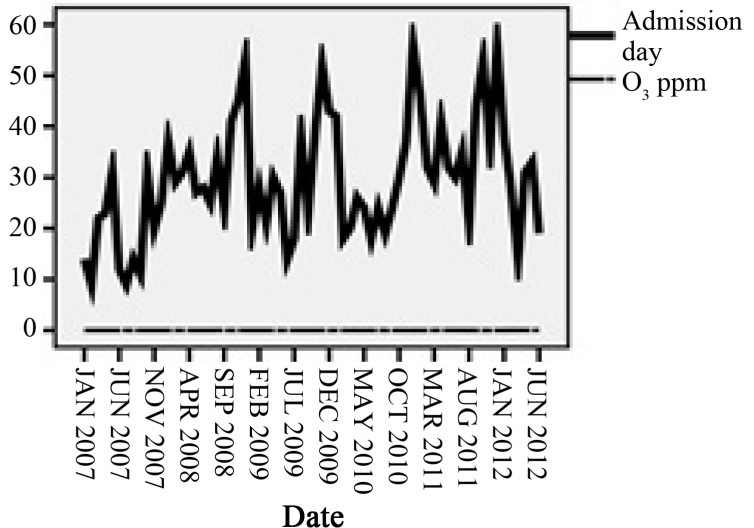

(b)

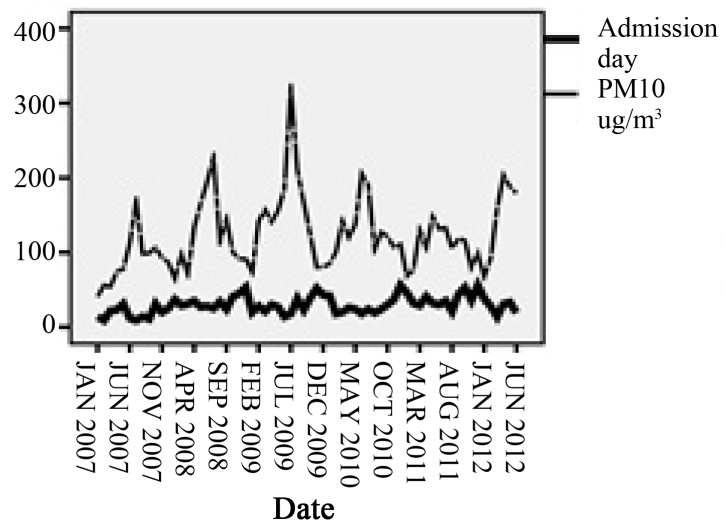

(d)

Date

(e)

Figure 1. Correlation of monthly mean air pollutant levels and number of hospital admissions of patients for asthma attack.

other studies in Iran [3] [13].

Ozone is an air pollutant related to sunlight. Because of the warm climate in our area, $\mathrm{O}_{3}$ concentration is high. Prolonged lung injury, oxidative stress, macrophage accumulation and extensive abnormal lung function have been reported in mice that inhaled $\mathrm{O}_{3}$ [14]. The results of a similar study in humans also indicated airway disruption and susceptibility to influenza infections [15]. In agreement with most epidemiologic studies especially from North America and Europe, exposure to $\mathrm{O}_{3}$ exacerbates asthma [16] [17]. 
Coal is still used as the main source of energy in some parts of Asia. The burning of coal emits a considerable amount of $\mathrm{SO}_{2}$ which increases bronchoconstriction in patients with asthma. We found a positive relationship between $\mathrm{SO}_{2}$ level and hospital admissions for asthma attack, which is in consistent with other reports from Iran and Turkey [3] [13] [18].

Among air pollutants, particulate matter has the greatest effects on human health [19]. However, in contrast to the results of similar studies in Tabriz and Tehran [19] [20], we found no significant association between $\mathrm{PM}_{10}$ levels and monthly admissions for asthma. The deposition of PM in the respiratory tract depends on the size of the particles as a strong correlation has been shown between $\mathrm{PM}_{2.5}$ and asthma morbidity [21].

Carbon monoxide, a marker of vehicle traffic, is a product of incomplete combustion of carbon-containing fuel. During the period covered by our study there were no reports of CO levels $\geq 9 \mathrm{ppm}$, the level considered toxic according to National Ambient Air Quality Standards (NAAQS) [22]. Our data showed no association between monthly concentrations of $\mathrm{CO}$ and exacerbations of asthma.

An analysis of the relationship between seasonal variations in asthma incidence and air pollutants in Taiwan showed strong associations with $\mathrm{PM}_{10}, \mathrm{O}_{3}$ and $\mathrm{SO}_{2}$ in children [23]. Our findings showed that the effect of $\mathrm{PM}_{10}$, $\mathrm{SO}_{2}$, $\mathrm{CO}$ and $\mathrm{O}_{3}$ on the rates of hospitalization of patients with asthma was higher during warm seasons. This may be a result of people spending more time outdoors and leaving windows open during the warm seasons, which can increase the exposure to $\mathrm{O}_{3}$ and other pollutants. We speculate that dust storms from neighboring countries also exacerbate asthma during warm seasons in our region.

Admission rates for patients with asthma are usually higher during cold seasons, which may be explained by the exacerbations of asthma after viral infections [2]. According to our results, only $\mathrm{NO}_{2}$ levels showed a greater association with the rates of admission of patients with asthma during the cold seasons than the warm seasons, a finding in line with the results reported by Castellsague et al. [24].

The stationary R-squared value and goodness-of-fit for the ARIMA model to predict monthly admissions were 0.523 and 0.62 , respectively. Based on our data, we predicted an increasing trend in monthly mean levels of air pollutants and numbers of patient admissions to 2015 (Figure 2).

Many studies suggest that the prevalence of asthma has reached a plateau or may be declining in developed countries, whereas it continues to increase in Asian countries. A factor that may be related to these opposing trends is that economic development in Asia is supported by the increased use of fossil fuels-which contribute to air pollution-as energy sources. On the basis of our data, we predicate that air pollution and asthma admission rates will be a major problem in 2015 in our region.

In this study we did not measure temperature, humidity and indoor allergens, all of which, along with air pollution, can affect asthma exacerbations. We recorded admission rates of patients with asthma at university hospitals only, and did not obtain data from private clinics and hospitals that also manage patients with asthma attacks in our region. Generally, different air pollutants interact with each other and an exact quantitation of each pollutant is rarely possible. The effect of air pollutants on asthma is likely to be a chronic process, and delayed

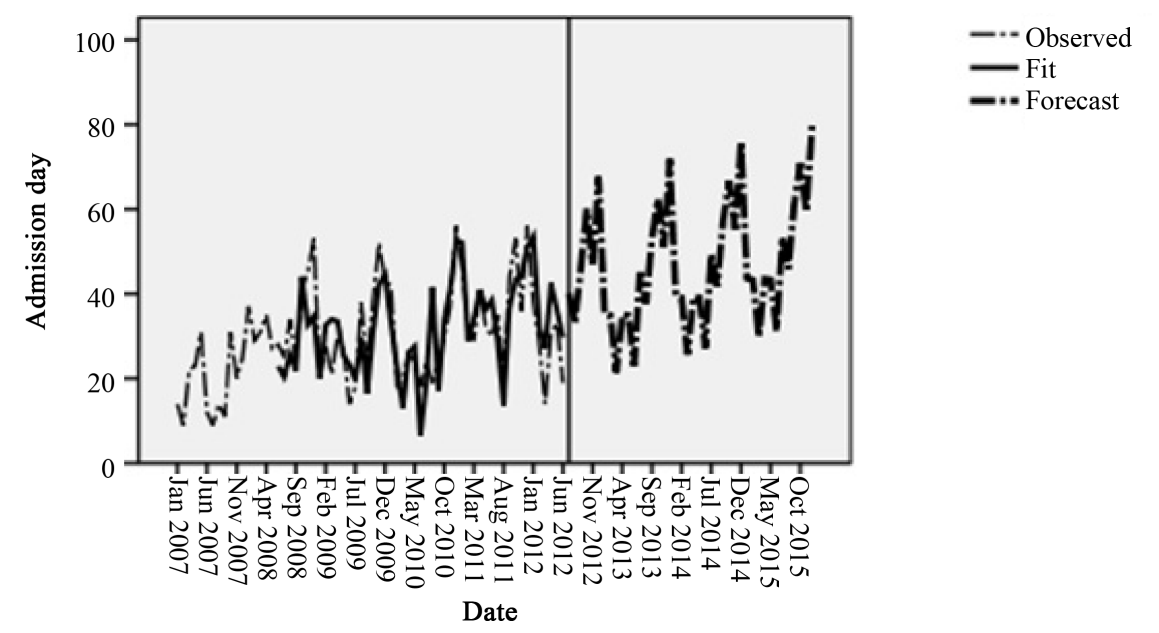

Figure 2. Forecast through 2015 of the trend in hospital admissions for asthma based on monthly mean levels of air pollutants. 
outcomes may appear long after exposure. Another potential limitation of this study is that we did not obtain follow-up data for our sample of patients later than mid-2012. We were not able to measure the concentration of $\mathrm{PM}_{2.5}$, and cannot speculate on the possible relationship between the levels of particles smaller than $\mathrm{PM}_{10}$ and hospital admissions for asthma in our setting.

\section{Conclusion}

Our results confirm the findings of previous studies of the effect of air pollution on asthma exacerbation. Further parallel studies are needed to evaluate the cumulative effects of meteorological factors, indoor allergen concentrations and outdoor air pollutants on asthma attack and admission rates. Because the prevention of asthma exacerbations is strongly preferable to emergency management, and because air pollution is a contributing factor, environmental protection measures aimed at controlling air pollution are advisable to prevent hospital admissions due to asthma attacks.

\section{Acknowledgements}

This work was supported by Shiraz University of Medical sciences (grant number 90-01-35-3936). We thank the Environmental Protection Department of Shiraz Municipality for their cooperation in air pollutant data collection. Our thanks go to K. Shashok (Author AID in the Eastern Mediterranean) for improving the use of English in the manuscript.

\section{References}

[1] Moghtaderi, M., Aleyasin, S., Amin, R. and Kashef, S. (2010) Skin Test Reactivity to Fungal Aeroallergens in Asthmatic Children in Southern Iran. Iranian Journal of Pediatrics, 20, 242-243.

[2] Matsumoto, K. and Inoue, H. (2014) Viral Infections in Asthma and COPD. Respiratory Investigation, 52, 92-100. http://dx.doi.org/10.1016/j.resinv.2013.08.005

[3] Gharehchahi, E., Mahvi, A.H., Amini, H., et al. (2013) Health Impact Assessment of Air Pollution in Shiraz, Iran: A Two-Part Study. Journal of Environmental Health Science and Engineering, 11, 11. http://dx.doi.org/10.1186/2052-336X-11-11

[4] Cirera, L., García-Marcos, L., Giménez, J., et al. (2012) Daily Effects of Air Pollutants and Pollen Types on Asthma and COPD Hospital Emergency Visits in the Industrial And Mediterranean Spanish City of Cartagena. Allergologia et Immunopathologia, 40, 231-237. http://dx.doi.org/10.1016/j.aller.2011.05.012

[5] Santus, P., Russo, .A, Madonini, E., et al. (2012) How Air Pollution Influences Clinical Management of Respiratory Diseases. A Case-Crossover Study in Milan. Respiratory Research, 13, 95. http://dx.doi.org/10.1186/1465-9921-13-95

[6] Villeneuve, P.J., Chen, L., Rowe, B.H. and Coates, F. (2007) Outdoor Air Pollution and Emergency Department Visits for Asthma among Children and Adults: A Case-Crossover Study in Northern Alberta, Canada. Environmental Health, 6, 40. http://dx.doi.org/10.1186/1476-069X-6-40

[7] Holguin, F. (2008) Traffic, Outdoor Air Pollution, and Asthma. Immunology and Allergy Clinics of North America, 28, 577-588. http://dx.doi.org/10.1016/j.iac.2008.03.008

[8] Encyclopedia of Earth (2013) Clean Air Act of the United States, 2007. http://www.eoearth.org/article/Clean_Air_Act,_United_States

[9] Chung, K.F., Zhang, J. and Zhong, N. (2011) Outdoor Air Pollution and Respiratory Health in Asia. Respirology, 16, 1023-1026. http://dx.doi.org/10.1111/j.1440-1843.2011.02034.x

[10] Schaumann, F., Borm, P.J., Herbrich, A., et al. (2004) Metal-Rich Ambient Particles (Particulate Matter 2.5) Cause Airway Inflammation in Healthy Subjects. American Journal of Respiratory and Critical Care Medicine, 170, 898903. http://dx.doi.org/10.1164/rccm.200403-4230C

[11] Tenías, J.M., Ballester, F. and Rivera, M.L. (1998) Association between Hospital Emergency Visits for Asthma and Air Pollution in Valencia, Spain. Occupational and Environmental Medicine, 55, 541-547. http://dx.doi.org/10.1136/oem.55.8.541

[12] Belanger, K., Gent, J.F., Triche, E.W., Bracken, M.B. and Leaderer, B.P. (2006) Association of Indoor Nitrogen Dioxide Exposure with Respiratory Symptoms in Children with Asthma. American Journal of Respiratory and Critical Care Medicine, 173, 297-303. http://dx.doi.org/10.1164/rccm.200408-1123OC

[13] Masjedi, M.R., Jamaati, H.R., Dokouhaki, P., et al. (2003) The Effects of Air Pollution on Acute Respiratory Conditions. Respirology, 8, 213-230. http://dx.doi.org/10.1046/j.1440-1843.2003.00455.x 
[14] Groves, A.M., Gow, A.J., Massa, C.B., Laskin, J.D. and Laskin, D.L. (2012) Prolonged Injury and Altered Lung Function after Ozone Inhalation in Mice with Chronic Lung Inflammation. American Journal of Respiratory Cell and Molecular Biology, 47, 776-783. http://dx.doi.org/10.1165/rcmb.2011-04330C

[15] Kesic, M.J., Meyer, M., Bauer, R. and Jaspers, I. (2012) Exposure to Ozone Modulates Human Airway Protease/Antiprotease Balance Contributing to Increased Influenza A Infection. PLoS ONE, 7, e35108. http://dx.doi.org/10.1371/journal.pone.0035108

[16] Gent, J.F., Triche, E.W., Holford, T.R., et al. (2003) Association of Low-Level Ozone and Fine Particles with Respiratory Symptoms in Children with Asthma. Journal of the American Medical Association, 290, 1859-1867. http://dx.doi.org/10.1001/jama.290.14.1859

[17] White, M.C., Etzel, R.A., Wilcox, W.D. and Lloyd, C. (1994) Exacerbations of Childhood Asthma and Ozone Pollution in Atlanta. Environ Res, 65, 56-68. http://dx.doi.org/10.1006/enrs.1994.1021

[18] Kara, E., Özdilek, H.G. and Kara, E.E. (2013) Ambient Air Quality and Asthma Cases in Niğde, Turkey. Environmental Science and Pollution Research, 20, 4225-4234. http://dx.doi.org/10.1007/s11356-012-1376-0

[19] Naddafi, K., Hassanvand, M.S., Yunesian, M., et al. (2012) Health Impact Assessment of Air Pollution in Megacity of Tehran, Iran. Iranian Journal of Environmental Health Science \& Engineering, 9, 28. http://dx.doi.org/10.1186/1735-2746-9-28

[20] Gholampour, A., Nabizadeh, R., Naseri, S., et al. (2014) Exposure and Health Impacts of Outdoor Particulate Matter in Two Urban and Industrialized Area of Tabriz, Iran. Journal of Environmental Health Science and Engineering, $12,27$. http://dx.doi.org/10.1186/2052-336X-12-27

[21] Pope, 3rd, C.A., Ezzati, M. and Dockery, D.W. (2013) Fine Particulate Air Pollution and Life Expectancies in the United States: The Role of Influential Observations. Journal of the Air \& Waste Management Association, 63, 129132. http://dx.doi.org/10.1080/10962247.2013.760353

[22] Lee, S.Y., Chang, Y.S. and Cho, S.H. (2013) Allergic Diseases and Air Pollution. Asia Pac Allergy, 3, 145-154. http://dx.doi.org/10.5415/apallergy.2013.3.3.145

[23] Yeh, K.W., Chang, C.J. and Huang, J.L. (2011) The Association of Seasonal Variations of Asthma Hospitalization with air Pollution among Children in Taiwan. Asian Pacific Journal of Allergy and Immunology, 29, 34-41.

[24] Castellsague, J., Sunyer, J., Sáez, M. and Antó, J.M. (1995) Short-Term Association between Air Pollution and Emergency Room Visits for Asthma in Barcelona. Thorax, 50, 1051-1056. http://dx.doi.org/10.1136/thx.50.10.1051 